\title{
Effects of Tillage and Manure on Emergence and Establishment of Russian Wildrye in a Saltgrass Meadow
}

\author{
D.M. MUELLER, R.A. BOWMAN, AND W.J. MCGINNIES
}

Saltgrass [Distichlis stricta (Torr.) Rydb.] meadows are found in lowland areas throughout the western United States. Saltgrass meadows are frequently more moist than upland sites and have good production potential if relatively unpalatable saltgrass is replaced by a more palatable species. The electrical conductivity and sodium absorption ratio of saltgrass meadow soils often increase with soil profile depth, while total $\mathbf{N}$ and sodiumbicarbonate extractable $\mathbf{P}$ decrease. Cultural practices that do not mix the deeper, more saline horizons with the surface should increase seedling germination and establishment. Field studies evaluated the effects of chisel plowing followed by vertical-axis tilling, conventional tilling (moldboard-plowing and discing), and manure $(0,11,22,45$, and $90 \mathrm{Mg} / \mathrm{ha})$ on soil physical and chemical characteristics as they relate to germination and establishment of Russian wildrye [Elymus junceus Fisch.]. Chisel plowing followed by vertical-axis tilling increased seedling emergence by $23 \%$ over conventional tillage. Manure increased seedling growth and emergence, but had no effect on stand ratings. The poor physical conditions created on the conventionally tilled plots when the B and $C$ horizons were brought to the surface and organic matter was buried by the plow are believed to have caused the difference in seedling counts between the two tillage treatments.

Saltgrass [Distichlis stricta (Torr.) Rydb.] meadows, found on lowland sites throughout the western United States, cover an estimated 500,000 ha in Colorado and Wyoming (Osborn 1974). These meadows are frequently more moist than upland sites and have good production potential if low-value saltgrass is replaced by more palatable species (Ludwig and McGinnies 1978). However, reclaiming salt-affected soils under semiarid conditions without irrigation water is difficult. These lands are usually marginally productive and precipitation is inadequate to leach salts from the root zone. Soil crusting, low fertility, high soluble salt concentrations, high exchangeable sodium, and poor soil structure limit establishment of more desirable species (Ludwig 1976).

Although chemical and organic amendments have been used to rehabilitate dryland saline-sodic soils in the past (Carter et al. 1977, Bower et al. 1951), the quantity of chemicals needed in order to have any ameliorative effect may be uneconomical (Downey 1971, Doering and Willis 1975). Cultural practices such as deep plowing provide an alternative to chemical and organic amendments. Deep plowing increased root penetration, infiltration rates, and yields on saline soils in Canada and North Dakota (Cairns 1967, Sandoval and Richman 1971). However, deep plowing should be avoided on soils that have a highly saline-sodic $\mathrm{C}$ horizon that is low in calcium, because of reduced yields when the $C$ horizon is mixed with the A and B horizons (McGinnies and Ludwig 1977). Plowing also may create problems in seedbed preparation by bringing the hard B horizon to the surface (Toogood and Cairns 1978). Therefore, studies were undertaken to identify and evaluate cultural practices that would not bring detrimental subsurface horizons to the surface, and to determine whether manure would help amelio-

\footnotetext{
Authors are range scientist, soil scientist, and range scientist, respectively, USDAARS Crops Research Laboratory, Colorado State University, Fort Collins 80523.

This article is a cooperative investigations of USDA-ARS, Fort Collins, Colo., and the Colorado Agricultural Experiment Station, Fort Collins.

Manuscript accepted February 20, 1985.
}

rate the physical and fertility problems associated with saltgrass soils.

\section{Study Area and Methods}

The study area was located along Eastman Creek on a saltgrass meadow at the Central Plains Experimental Range, 19 km northeast of Nunn, Colo. The mean annual precipitation is $31 \mathrm{~cm}$ with 85\% occurring between May and September. Precipitation for 1981 and 1982 was 29.9 and $41.7 \mathrm{~cm}$, respectively. Summer temperatures range from an average minimum of $9.0^{\circ} \mathrm{C}$ to an average maximum of $25.5^{\circ} \mathrm{C}$. The mean annual temperature is $8.0^{\circ} \mathrm{C}$. Annual average wind velocity is $10.3 \mathrm{~km} / \mathrm{h}$ and the frostfree growing period averages 133 days. Soils on the saltgrass meadow are mostly fine-loamy mixed mesic Ustollic Natrargids of the Avar fine sandy loam series. Soluble salt concentrations and exchangeable sodium increase and fertility decreases with depth (Mueller 1983). The $C$ horizon contains low concentrations of calcium and high concentrations of carbonates, bicarbonates, sulfates, and sodium (McGinnies and Ludwig 1978). Existing dominant species are inland saltgrass, alkali sacaton (Sporobolus airoides Torr.), blue grama [Bouteloua gracilis (H.B.K.) Lag.], western wheatgrass (Agropyron smithii Rydb.), and sedges (Carex spp.) (McGinnies et al. 1976).

A field study was initiated in the fall of 1980 to compare the effects of chisel plowing followed by tilling with a tiller that mixes the soil horizontally (vertical-axis tillage) with effects of plowing and discing (conventional tillage), both at 5 levels of manure $(0,11$, 22,45 , and $90 \mathrm{Mg} / \mathrm{ha}$ ) on the establishment of Russian wildrye (Elymus junceus Fisch. 'Vinall'). Four replicates were established on an area that had been sprayed with $4.6 \mathrm{~kg} /$ ha of glyphosate [N(phosphonmethyl) glycine] to control saltgrass in August of 1978 and 1980. The other 4 replicates of the study were located adjacent to the first on an area that was sprayed with glyphosate only in August 1980. Half of each replication was moldboard plowed to a depth of $20 \mathrm{~cm}$ in the fall of 1980; the other half was vertical-axis tilled to the same depth in the spring of 1981 after chisel plows, set $0.3 \mathrm{~m}$ apart and $20 \mathrm{~cm}$ deep, were used to loosen the sod.

Five levels of manure were randomly applied to subplots within each replication of each tillage treatment in the spring of 1981 . The manure plots were $2.9-$ by $4.7-\mathrm{m}$. The manure was incorporated into the soil with a disc on the conventionally tilled treatments, and with the vertical-axis tiller on the vertical-axis tilled treatment. All plots were cultipacked and then planted on 24 April 1981 to Russian wildrye, in rows $0.3 \mathrm{~m}$ apart at 100 live seeds per meter of row, with a double-disc drill equipped with 2-cm depth bands.

Seedlings were counted and height measured 3-4 June and 14-21 July 1981. Stands were rated 24-29 September 1981 and 25 August 1982 on a scale from 0 to 10 with 0 representing no seedling establishment and 10 representing the maximum stand that could be expected on that particular site (McGinnies et al. 1983). Seedling counts and ratings were made on four $0.9-\mathrm{m}$ segments in separate rows within the middle of each subplot.

Soil moisture to a depth of $20 \mathrm{~cm}$ was determined gravimetrically on the 0,22 , and $90 \mathrm{Mg}$ / ha manure plots immediately after a heavy rain that fell 18 May 1981 . Soil samples were taken on 7 July 
1981 from the 0,22 , and $90 \mathrm{Mg}$ / ha manure plots at depth increments of 0 to 10 and 10 to $20 \mathrm{~cm}$. Sodium-bicarbonate extractable phosphorus (Olsen and Dean 1965), total Kjeldahl nitrogen (Bremner 1965), pH, electrical conductivity (EC), sodium adsorption ratio (SAR) (Richards 1954), and texture (Day 1965) were determined on the 0 to 10 - and 10 to $20-\mathrm{cm}$ soil samples. On 16 November 1981, soil samples taken from the surface $(2 \mathrm{~cm})$ of each treatment were analyzed for texture, $\mathrm{NaHCO}_{3}$-extractable $\mathrm{P}, \mathrm{pH}$, EC, and SAR. Soil samples were air dried and passed through a l-mm screen before analysis. All soil samples and moisture data were taken from the 4 replications which had been previously sprayed in 1978 and 1980.

Weeds were controlled by a single application of 2,4-D [(2,4dichlorophenoxy)acetic acid)] at $0.37 \mathrm{~kg} / \mathrm{ha}$ in June 1981 , and by a hand-pushed power mower in July and August.

To analyse the plant data a split-split-plot analysis of variance was used, after the variance of the 2 areas were found to be homogeneous. Areas, tillage treatment, and manure rate were main, sub-, and sub-sub-plots, respectively. A randomized block in a split-plot analysis of variance was used to evaluate the soils and moisture data. Conventional linear multiple regression techniques were used where appropriate.

\section{Results and Discussion}

It was assumed that the vertical-axis tiller, which mixes soil horizontally but not vertically with its tines, would avoid bringing the deeper salt-affected horizons to the surface. The 0 to $10 \mathrm{~cm}$ soil depth on the vertical-axis tilled treatments had significantly $(P \leq 0.05)$ lower $\mathrm{pH}$ and SAR values and significantly $(P \leq 0.05)$ higher $N$ and $P$ values than the 10 to $20 \mathrm{~cm}$ soil depth (Table 1).

Table 1. Effect of tillage and depth on pH, EC, SAR, total N, and NaHCO ${ }^{3}$-extractable $P$ of soils collected July 7, 1981 at depths of 0 to 10 and 10 to $20 \mathrm{~cm}^{1}$

\begin{tabular}{lccccc}
\hline & \multicolumn{2}{c}{ Vertical-Axis Tillage } & & \multicolumn{2}{c}{ Conventional Tillage } \\
\cline { 2 - 3 } \cline { 5 - 6 } Soil parameters & $\begin{array}{c}\text { Depth } \\
(0-10 \mathrm{~cm})\end{array}$ & $\begin{array}{c}\text { Depth } \\
(10-20 \mathrm{~cm})\end{array}$ & & $\begin{array}{c}\text { Depth } \\
(0-10 \mathrm{~cm})\end{array}$ & $\begin{array}{c}\text { Depth } \\
(10-20 \mathrm{~cm})\end{array}$ \\
\hline pH & $7.0 \mathrm{a}$ & $7.5 \mathrm{~b}$ & & $7.4 \mathrm{x}$ & $7.4 \mathrm{x}$ \\
EC $(\mathrm{dS} / \mathrm{m})$ & $1.8 \mathrm{a}$ & $1.5 \mathrm{a}$ & & $1.8 \mathrm{x}$ & $1.8 \mathrm{x}$ \\
SAR & $4.0 \mathrm{a}$ & $6.4 \mathrm{~b}$ & & $5.0 \mathrm{x}$ & $5.3 \mathrm{x}$ \\
$\mathrm{N}(\mathrm{ug} / \mathrm{g})$ & $1590 \mathrm{~b}$ & $1029 \mathrm{a}$ & & $1089 \mathrm{x}$ & $1694 \mathrm{y}$ \\
P $(\mathrm{ug} / \mathrm{g})$ & $41.1 \mathrm{~b}$ & $14.0 \mathrm{a}$ & & $16.7 \mathrm{x}$ & $18.9 \mathrm{x}$ \\
\hline
\end{tabular}

IMeans within each tillage treatment with same letter are not significantly different $(P \leq 0.05)$.

This same trend was observed in a baseline study done on undisturbed sites within the saltgrass area (Mueller 1983). Therefore little vertical mixing of the original soil profile occurred as a result of vertical-axis tillage.

On the conventionally tilled plots, total $N$ in the 0 to $10 \mathrm{~cm}$ soil depth was significantly $(P \leq 0.05)$ lower than total $\mathrm{N}$ in the 10 to $20-\mathrm{cm}$ soil depth. There were no significant $(P \leq 0.05)$ differences between sampling depths for other soil parameters (Table 1), but surface $\mathrm{pH}$ and SAR were significantly $(P \leq 0.05)$ higher on the conventionally tilled plots than on the vertical-axis tilled plots (Table 2). These data indicated that plowing deposited some salinesodic horizon material on the surface while simultaneously burying the thin topsoil layer, high in organic matter and N. Subsequent discing, which was not as deep as the plowing, thoroughly mixed the saline-sodic material initially deposited on the surface, and thus reduced differences in salinity between depths (the disc penetrated to an average of $15 \mathrm{~cm}$ ).

Russian wildrye seedlings were taller on the vertical-axis tilled plots. Vertical-axis tillage increased seedling emergence (June 3-4) by $23 \%$ over conventional tillage (Table 3 ). Seedling counts and stand ratings on the vertical-axis tilled plots remained significantly $(P \leq 0.05)$ higher throughout 1981 and 1982.
Tahle 2. Effect of tillage on pH, EC, SAR, and texture of surface soils $(0-2.0 \mathrm{~cm})$ collected November $16,1981 .^{1}$

\begin{tabular}{lcc}
\hline \hline & \multicolumn{2}{c}{ Tillage } \\
\cline { 2 - 3 } Soil Parameters & Conventional & Vertical-Axis \\
\hline pH & $7.6 \mathrm{~b}$ & $7.2 \mathrm{a}$ \\
EC $(\mathrm{dS} / \mathrm{m})$ & $1.8 \mathrm{a}$ & $0.8 \mathrm{a}$ \\
SAR & $4.4 \mathrm{~b}$ & $1.1 \mathrm{a}$ \\
Sand $(\%)$ & $45.0 \mathrm{a}$ & $37.0 \mathrm{a}$ \\
Silt $(\%)$ & $26.0 \mathrm{a}$ & $35.0 \mathrm{~b}$ \\
Clay $(\%)$ & $29.0 \mathrm{a}$ & $28.0 \mathrm{a}$ \\
\hline
\end{tabular}

${ }^{1}$ Means with the same letter are not significantly different $(P \leq 0.05)$.

Table 3. Effect of tillage treatment and manure application rate on seedling heights and stand during 1981 and 1982.1

\begin{tabular}{|c|c|c|c|}
\hline Plant Measurements & $\begin{array}{l}\text { Days After } \\
\text { Planting }\end{array}$ & $\frac{\text { Tillage }}{\text { Conventional }}$ & $\overline{\text { Vertical-axis }}$ \\
\hline $\begin{array}{l}\text { Seedling Heights, cm } \\
\text { June } 3-4,1981\end{array}$ & $40-41$ & $6.7 \mathrm{a}$ & $8.1 \mathrm{~b}$ \\
\hline $\begin{array}{l}\text { Seedlings } / m \text { row } \\
\text { June }-4,1981\end{array}$ & $40-41$ & $29.0 \mathrm{a}$ & $36.0 \mathrm{~b}$ \\
\hline $\begin{array}{l}\text { Seedlings } / \mathrm{m} \text { row } \\
\text { July } 14-21,1981\end{array}$ & $81-88$ & $22.0 \mathrm{a}$ & $28.0 \mathrm{~b}$ \\
\hline $\begin{array}{l}\text { Stand Rating } \\
(0=\text { none, } 10=\text { solid }) \\
\text { September } 15-25,1981\end{array}$ & $158-168$ & $3.9 \mathrm{a}$ & $5.4 \mathrm{~b}$ \\
\hline $\begin{array}{l}\text { Stand Rating } \\
(0=\text { none, } 10=\text { solid }) \\
\text { August } 25,1982\end{array}$ & 439 & $5.9 \mathrm{a}$ & $7.0 \mathrm{~b}$ \\
\hline
\end{tabular}

${ }^{1}$ Means with the same letter are not significantly different $(P \leq 0.05)$.

Better establishment was expected after vertical-axis tillage than after conventional tillage because plowing was suspected of increasing surface salinity and sodicity to levels that would inhibit either germination or seedling establishment. Although plowing produced average surface $\mathrm{pH}$ and $\mathrm{SAR}$ values that were significantly $(P \leq 0.05)$ higher than on the vertical-axis tilled treatments, germination and establishment with conventional tillage was still high. Russian wildrye has been considered to be well adapted to moderately salty lands (Plummer et al. 1955, Rauser and Crowle 1963). However, the range of SAR (0.44 to 11.62) on the conventionally tilled treatments reached levels that could have an adverse

Table 4. Regression equation for seedlings $/ \mathrm{m}$ (S) and seedling ht. (cm)(H) on conventionally tilled and vertical-axis tilled plot as a function of manure application rate (Mg/ha) (M).

\begin{tabular}{lll}
\hline \hline Tillage & Regression equation & $R^{2}$ \\
\hline Conventional & $\mathrm{S}=26.88+0.05 \mathrm{M}$ & .63 \\
& $\mathrm{H}=5.67+0.03 \mathrm{M}$ & .97 \\
Vertical-axis & $\mathrm{S}=33.09+0.07 \mathrm{M}$ & .95 \\
& $\mathrm{H}=6.72+0.46 \mathrm{Logan}(\mathrm{M}+1)$ & .92 \\
\hline
\end{tabular}

effect on soil physical properties (Jayawardane and Beattie 1978) and thus on seedling emergence and survival. Linear multiple regression showed the first seedling count on the conventionally tilled plots to be highly correlated with clay content, SAR, EC, and manure $(R=0.84)$. Clay content and SAR were negatively correlated with seedling counts, whereas EC and manure were positively correlated. There were no significant $(P \leq 0.05)$ negative correlations between the first seedling count and surface soil parameters on the vertical-axis tilled plots. 
Past studies have shown that the combination of montmorrillonite clay, high $\mathrm{Na}$, and low organic matter can result in poor soil physical properties (Richards 1954, Lemos and Lutz 1957). Frequent and severe crusting as well as rough, cloddy seedbed were observed in areas where seedling stands were poor. Therefore, the poor physical conditions on the conventionally tilled plots, created when the sodic $B$ and $C$ horizons were brought to the surface and the $\mathrm{A}$ horizon with its high organic matter content was buried, are believed to have resulted in the difference in seedling counts between the two tillage treatments.

The vertical-axis tiller broke clods into smaller aggregates and produced a smoother, more level seedbed than a disc and harrow. This may have also contributed to the higher seedling count on the vertical-axis tilled plots by providing better contact between seed and soil and a more uniform planting depth. However, both vertical-axis tilling and/or discing and harrowing can result in a poor seedbed when saline-sodic horizons are brought to the surface. Toogood and Cairns (1978) have also reported that plowing created problems in seedbed preparation on Solonetzic soils by bringing the hard $B$ horizon to the surface.

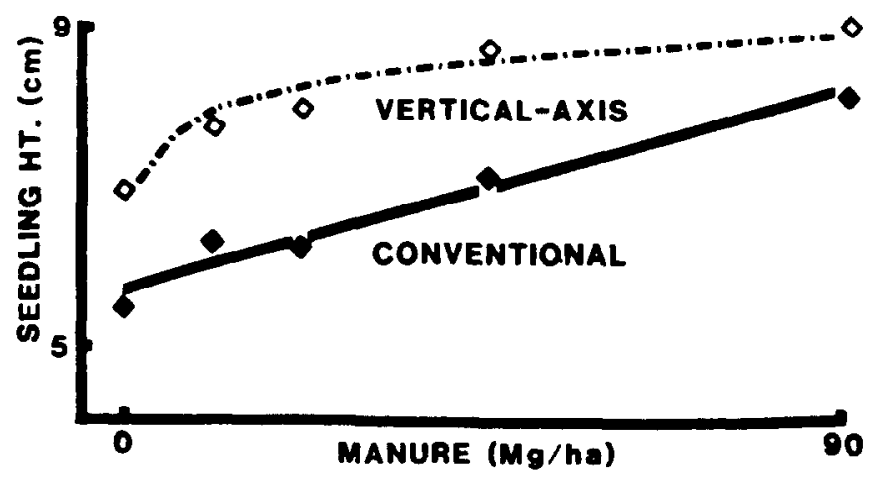

Fig. 1. Relationship between seedling and manure on the vertical-axis and conventionally tilled plots during June 1981.

Vertical-axis tilling failed to bury most weed seeds deeply enough to prevent their germination and emergence, resulting in abundant weed growth, predominately summer-cypress [Kochia scoparia (L.) Schrad.] and lambsquarter (Chenopodium album L.). Better weed control would have probably resulted in even greater differences between the two tillage treatments.

Regression analysis showed a positive effect of manure on earlyJune seedling heights and emergence (Fig. 1 and Fig. 2). The effect

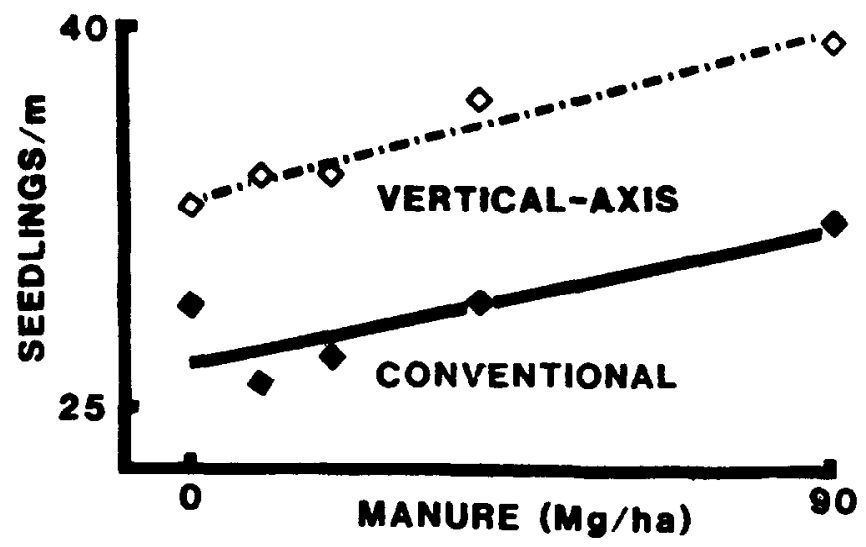

Fig. 2. Relationships between seedlings/ $m$ and manure on the vertical-axis and conventionally tilled plots during June 1981. of manure on seedling heights within the vertical-axis tilled plots decreased at application rates above $11 \mathrm{Mg} / \mathrm{ha}$. Seedling heights on the conventionally-tilled plots and seedlings $/ \mathrm{m}$ on both tillage treatments increased linearly throughout the manure application rates used in the study. Reasons for responses of Russian wildrye to manure cannot be definitively determined from the data. Although nitrogen and phosphorus levels were significantly $(P \leq 0.05)$ higher than the control on the $90 \mathrm{Mg}$ / ha manure plots, regression analysis did not show any significant positive correlations between these soil parameters and seedling heights or seedling counts. Verticalaxis tilled plots had higher soil water content than conventionaltilled plots at $(P \leq 0.10)$ but there was no difference in soil water content between manure treatments.

The vertical-axis tiller produced a better seedbed than conventional tillage methods by breaking the soil into smaller aggregates, not bringing saline horizons to the surface, leaving organic matter on the surface, and reducing the severity and frequency of soil crusting.

To avoid bringing the $B$ or $C$ horizon to the surface, chisel plowing followed by vertical-axis tilling is recommended on areas that have a shallow A horizon (less than $20 \mathrm{~cm}$ ). If the A horizon is deep (greater than $20 \mathrm{~cm}$ ) moldboard plowing followed by verticalaxis tilling is recommended, because moldboard plowing controls the weeds better than chisel plowing. Russian wildrye emergence and establishment were improved by using a vertical-axis tiller on the saltgrass meadow. Although the vertical-axis tiller did not control weeds as well as conventional tillage, it produced a better seedbed.

\section{Literature Cited}

Bower, C.A., L.R. Swarner, A.W. Marsh, and F.M. Tileston. 1951. The improvement of an alkali soil by treatment with manure and chemical amendments. Tech. Bull. 22, Oregon Agr. Exp. Sta., Corvallis.

Bremner, J.M. 1965. Inorganic forms of nitrogen. p. 1179-1237. In: C.A. Black (ed.), Methods of Soil Analysis. Agron. 9:1179-1237. Amer. Soc. Agron., Madison, Wisc.

Cairns, R.R. W.E. Bowser, R.A. Milne, and P.C. Chang. 1967. Effects of nitrogen fertilization on bromegrass grown on Solenetzic soils. Can. J. Soil Sci. 47:1-6.

Carter, M.R., R.R. Cairns, and G.R. Webster. 1977. Amelioration of a Brown Solodized soil by a surface application of gypsum plus ammonium nitrate. Can. J. Soil. Sci. 57:139-145.

Day, P.R. 1965. Particle fractionation and particle-size analysis. p. 545 567. In: C.A. Black (ed.), Methods of Soil Analysis. Agron. 9:545-567. Amer. Soc. Agron., Madison, Wisc.

Doering, E.J., and W.O. Willis. 1975. Chemical reclamation for sodic strip-mine spoils. A.R.S. Pub. NC-20. Agr. Res. Serv., USDA.

Downey, L.A. 1971. Physical problems and their amelioration in salty soils. J. Aust. Inst. Agr. Sci. 37:314-326.

Jayawardane, N.S., and J.A. Beattie. 1978. Effect of salt solution composition on moisture release curves of soil. Aust. J. Soil. Res. 17:89-99.

Lemos, P., and J.F. Lutz. 1957. Soil crusting and some factors affecting it. Soil Sci. Soc. Amer. Proc. 21:485-491.

Ludwig, J.R. 1976. Revegetation of a saltgrass meadow in northeastern Colorado. Ph.D. Thesis, Range Sci. Dep., Colorado State Univ., Fort Collins, Colo.

Ludwig, J.R., and W.J. McGinnies. 1978. Revegetation trials on a saltgrass meadow. J. Range Manage. 31:308-311.

McGinnies, W.J., W.G. Hassell, and C.H. Wasser. 1983. A summary of range seeding trials in Colorado. Special series 21, Coop. Ext. Service, Colorado State Univ., Fort Collins.

McGinnies, W.J., and J.R. Ludwig. 1977. Effects of Naturstoll (Solonetz) soil horizons and nitrogen on growth of tall wheatgrass. Agr. J. 69:518-520.

McGinnies, W.J., and J.R. Ludwig. 1978. Effects of Naturstoll soil horizons on germination, emergence, and growth of four grasses. Agron. J. 70:1086-1088.

McGinnies, W.J., L.W. Osborn, and A.B. Berg. 1976. Plant-soil-microsite relationships on a saltgrass meadow. J. Range Manage. 39:395-400.

Mueller, D.M. 1983. Establishment of Russian wildrye on a saltgrass meadow. M.S. Thesis, Range Sci. Dep. Colorado State Univ., Fort Collins . 
Olsen, S.R., and L.A. Dean. 1965. Phosphorus. In. C.A. Black (ed.), Methods of Soil Analysis. Agron. 9:1035-1048. Amer. Soc. Agron., Madison, Wisc.

Osborn, L.W. 1974. Soil-plant relationships in a saltgrass meadow. M.S. Thesis, Range Sci. Dep. Colorado State Univ., Fort Collins.

Plummer, A.P., A.C. Hull, Jr., G. Stewart, and J.H. Robertson. 1955. Seeding rangelands in Utah, Nevada, southern Idaho and western Wyoming. USDA Handbook No. 71 .
Rauser, W.E., and W.L. Crowle. 1963. Salt tolerance of Russian wild ryegrass in relation to tall wheatgrass and slender wheatgrass. Can. J. Plant Sci. 43:397-407.

Richards, L.A. (ed.). 1954. Diagnosis and improvement of saline and alkali soils. USDA Handbook No. 60.

Sandoval, F.M., and G.A. Reichman. 1971. Some properties of solonetzic (sodic) soil in western North Dakota. Can. J. Soil Sci. 51:143-155.

Toogood, J.A., and R.R. Cairns. 1978. Solonetzic soils technology and management. Bull. B-78-1 Dep. Ext. Univ. Alberta, Edmonton. 